\title{
SMALL NONPROFITS UNFAMILIAR WITH SARBANES-OXLEY FAILED TO ESTABLISH WHISTLEBLOWER PROTECTIONS
}

\author{
Matthew R. Kisow, M. Sc., NSABP Foundation, Inc., matt.kisow@nsabp.org
}

\begin{abstract}
The whistleblower protections under the Sarbanes-Oxley act apply to all organizations, however almost all small nonprofit organizations unfamiliar with this legislation do not have whistleblower protection policies for their employees. Compounding this issue are the 2008 tax year revisions to IRS form 990 that now require nonprofit organizations to document whether they have adopted document retention, whistleblower protection, and conflicts of interest governance controls. Targeting Pennsylvania nonprofit organizations, the research carried out in this study sought to discover what impact an organizations unfamiliarity with the Sarbanes-Oxley act had on their compliance with this federal legislation. The research findings indicated that almost two-thirds of small nonprofit organizations that were not familiar with the Sarbanes-Oxley act did not have whistleblower protections for their employees.
\end{abstract}

Keywords: Sarbanes-Oxley Act, IRS Form 990, Nonprofit Sector, Business

\section{INTRODUCTION}

Congress, concerned over the need for greater transparency and accountability across all sectors mandated the whistleblower and document retention regulations in the Sarbanes-Oxley act applicable to all organizations. Although this act applies primarily to publicly traded organizations, the whistleblower provision protects employees who report suspected violations of state and federal law from retaliation by their employer.

The whistleblower protection and document retention regulations $[9,12,13,24]$ were revised when the SarbanesOxley Act of 2002 was signed into law. However, beginning in the 2009 tax year, a revised Form 990 designed to enhance the transparency and accountability of the nonprofit sector has been put in place by the IRS to further enhance the nonprofit sector's governance [23, 25]. Orlikoff \& Totten [16] point out that underwriters and liability insurers now require nonprofit organizations to voluntarily provide these measures in their governance. Through this revised form, all nonprofit organizations must disclose whether they have whistleblower and document retention policies. Further disclosures are similar to the Sarbanes-Oxley act.

\section{PROBLEM STATEMENT}

The whistleblower protections under the Sarbanes-Oxley act apply to all organizations, but less than one percent of small nonprofit organizations that are unfamiliar with the Sarbanes-Oxley act are in compliance with this regulation.

\section{PURPOSE OF STUDY}

The purpose of this research study is to provide insight into how familiar Pennsylvania nonprofit organizations are with the Sarbanes-Oxley act, and to evaluate to what degree a nonprofit organization unfamiliar with the act is compliant with document retention, whistleblower protection, and conflicts of interest governance controls.

\section{RESEARCH QUESTIONS}

This empirical research targeted Pennsylvania nonprofit organizations, the research carried out in this study sought to discover what impact organizations unfamiliarity with the Sarbanes-Oxley act had on their compliance with this federal legislation. Specifically, this research study was conducted to examine the following research questions:

1. Are Pennsylvania nonprofit organizations familiar with the updated whistleblower provisions of the Sarbanes-Oxley Act? 
2. Have small Pennsylvania nonprofit organizations that are unfamiliar with the Sarbanes-Oxley Act implemented whistleblower provisions?

3. Have Pennsylvania nonprofit organizations that are familiar with the whistleblower provisions of the Sarbanes-Oxley Act implemented whistleblower provisions?

\section{PREVIOUS RESEARCH}

This study is based on a study conducted by Iyer \& Watkins, "Adoption of Sarbanes-Oxley Measures by Nonprofit Organizations: An Empirical Study" [13], which was conducted by surveying 600 South Carolina nonprofit organizations. The Iyer \& Watkins survey instrument was employed in part to answer the above research question.

\section{LIMITATIONS}

This research study is limited in scope by the data collection instrument and the demographics of the study's sample population. As noted above, the data for this study were captured using an instrument that had been used in a previous research study by Iyer \& Watkins (2008) [13], "Adoption of Sarbanes-Oxley Measures by Nonprofit Organizations: An Empirical Study", which addressed the adoption of Sarbanes-Oxley governance measures by nonprofit organizations. This instrument was adapted for the current research to address the adoption of SarbanesOxley governance measures as a result of the revised IRS Form 990. Changes in the revised version were minor in scope and are explained in the methodology section of this research project. The sample for this project was derived using a simple random sampling technique. Although every effort was made to ensure a representative sample of Pennsylvania nonprofit organizations, this research study realized a 2:1 ratio of large vs. small organizations represented among those who replied. It should be noted that the DoS dataset did not contain information related to budget or number of employees. These limitations placed constraints on the generalizability of the collected data. Therefore, every effort has been made to ensure that the conclusions drawn are representative of the population.

\section{REVIEW OF THE LITERATURE}

\section{Introduction}

Revisions to IRS Form 990 have placed undue burdens on small nonprofit organizations. The mandates in the revised Form 990 address the lack of the nonprofit sector's accountability and transparency over the past 12 years. Disclosures of fraud and abuse have required mid-sized and large nonprofit organizations to perform annual audits. Although whistleblower protection laws were revised with the Sarbanes-Oxley act few nonprofit organizations have whistleblower protection policies.

\section{Independent Audits}

All nonprofit organizations utilizing independent auditors should have independent audit committees. Independent audit committees of nonprofit organizations made up of independent members of the board of directors and the disclosure of at least one of these members as a financial expert is a requirement of section 407 of the SarbanesOxley Act $[13,18]$. This requirement exists so that the board of directors understands the financial statements and has the wherewithal to retain and supervise the external auditors $[1,13,18,20]$.

\section{Whistleblower Protection}

The whistleblower protections of Sarbanes-Oxley apply to both the public and nonprofit sectors. This provision protects employees by granting special damages and attorney's fees and prohibits employers from taking certain actions against workers who lawfully disclose information regarding a crime [1, 13, 18]. Sarbanes-Oxley also provides for criminal penalties for actions taken against whistleblowers. 
Volume XII, No. 1, pp. 44-53, 2011

\section{IRS Revisions to Form 990}

For the first time since 1979 The Federal Government has revised its IRS Form 990 to enhance the governance, transparency, and accountability of nonprofit organizations [1, 3, 10, 23]. Starting in the 2008 tax year, the redesigned 990 is meant to bridge the gaps in the previous 990 that had failed to meet the IRS's tax compliance interests and the transparency and accountability needs of the state and federal government [3,23]. This revised form is meant to minimize the burden of filing on nonprofit organizations as well as to promote tax compliance [10, 23]. The increased disclosure to the IRS and, inevitably, the scrutiny of donors to these organizations has incorporated the principles and best practices introduced by the Sarbanes-Oxley Act $[1,3,23]$.

These new requirements apply to all nonprofit organizations, which must now annually file a Form 990, and lower the thresholds at which nonprofit organizations must file from $\$ 2.5$ million to $\$ 500,000$ beginning in the 2010 tax year $[1,3,23]$. These changes seem to underscore the belief that the best practices developed under Sarbanes-Oxley and California's Nonprofit Integrity Act are no less relevant to nonprofit organizations [14, 18, 22, 23].

The relevance of transparency and accountability in nonprofit governance is clear. According to Bakale [1], there is concern among top officials of the federal government about issues of transparency among nonprofit organizations. Perhaps one of the core issues is poor governance. This issue has time and time again not kept up with modern practices and must be addressed [1,23].

\section{Past Research}

In a 2008 research study, "Adoption of Sarbanes-Oxley Measures by Nonprofit Organizations," in which 600 South Carolina nonprofit organizations were surveyed on the voluntarily adoption of Sarbanes-Oxley provisions, the authors concluded that "many nonprofit organizations already have governance measures similar to those prescribed in [Sarbanes-Oxley]" [13]. This same study pointed out, however, that some of the largest for profit organizations have not implemented the simplest aspects of Sarbanes-Oxley such as whistleblower protection and code of ethics and conduct policies [13]. Mulligan opines that the costly disclosure requirements of the Sarbanes-Oxley Act will do little to prevent the unethical behavior that seems to be running rampant in nonprofit governance [14].

\section{METHODOLOGY}

\section{Introduction}

The purpose of this research study is to discover what impact an organizations unfamiliarity with the SarbanesOxley act had on their compliance with whistleblower protections.

\section{Research Design}

This correlational study was approached from the epistemological perspective of post-positivism; the researcher used the tenant principles of the scientific method which, as Creswell [4] states, are "cause and effect thinking, reduction to specific variables and hypothesis and questions, use of measurement and observation, and test[s] of the theories." The relationships between size of an organization (predictor variable) and the secondary outcome variable (voluntary adoption of Sarbanes-Oxley) will be tested.

\section{Participants}

The participants were all 501(c)(3) non-profit organizations that file IRS Form 990 in Pennsylvania. To obtain this sampling frame I requested a list of all 501(c)(3) nonprofit organizations from Pennsylvania's Department of State. This electronic list contained the names, addresses and phone numbers of the organizations' contacts. The sampling procedure was done by randomly sorting this list and selecting the first $632(10 \%)$ organizations. By choosing $10 \%$ the sampling margin of error was less than $.01 \%$. E-mail addresses were added to each of these 632 records by searching the Internet for the organization's name and address. In the event an organization did not have electronic 
contact information available on the Internet, phone calls were made to request their participation. Of the 632 organizations contacted, $170(27 \%)$ were eliminated for the following reasons: 1) 97 (15\%) did not return the researcher's request for contact either by e-mail or phone call; 2) $35(5 \%)$ requested not to be included in the study; 3) 34 (5\%) expressed concerns over the confidentiality of the survey; and 4) $4(2 \%)$ no longer exist or had become for-profit entities.

Responses were received from 153 organizations. By budget size there were 62 organizations of $\$ 0-\$ 500,000$ and 91 organizations of $\$ 501,000->\$ 1,000,000$ By number of employees, there were 121 organizations with less than 100 employees and 32 organizations with greater than 100 employees. The individuals who responded were: Executive Directors (58), CEO (37), Vice President (17), Controller (14), Board Member (15) and 12 in the other category.

\section{Survey Instrument}

Iyer and Watkins [13] conducted a similar study in North Carolina using their own instrument that contained 31 questions. Because the instrument contained the kinds of questions suitable for answering my research questions, I adapted it, using 24 of their questions. The remaining 6 questions were removed from the survey because they did not pertain to my research.

This updated instrument contained 24 questions on six topics: demographics, awareness of Sarbanes-Oxley, audit committee and board of directors, whistleblower protections, certification of financial information, and internal accounting and information technology controls. The following sections describe each category and how the questions relate to the five research questions above.

The Demographics section of this survey contained four questions, with categorical responses. These questions asked the respondent's job title, whether the organization is headquartered in Pennsylvania the size of the organization's annual budget, and the number of employees the organization has. This information was used to describe the characteristics of the sample and to make inferences about the overall makeup of the sample.

The Awareness of Sarbanes-Oxley section of this survey contained two questions asking about familiarity with the Sarbanes-Oxley act and the IRS form 990. Responses options were "yes" or "no".

The Audit Committee and Board of Directors section of the survey contained nine questions to determine the organizations' overall financial control structures and independence. Response options for these questions were yes, no and ordinal.

The Whistleblower Protection section of the survey contained three questions to identify whether organizations have policies safeguarding employees that speak out against unethical abuses. Response options for these questions were yes, no and ordinal.

The Certification of Financial Information section of this survey contained two questions to determine how financial information is certified. The response options for these questions were yes and no.

The Internal Accounting and Information Technology Controls section of the survey contained four questions to determine how financial controls are implemented and certified. Response options for these questions were yes, no and ordinal.

\section{Data Collection Procedures}

Data collection occurred between June, 2010 and July 27, 2010. The researcher sent 462 e-mails that contained a hyper-link to the surveys. The e-mails were sent to the attention of the executive directors, CEO, Vice President, Controller or Board Members of the respective organizations. The email contained an introduction, explaining who I was and what information the study intended to collect and the hyperlink to the survey. Reminder notices were sent 
Volume XII, No. 1, pp. 44-53, 2011

bi-weekly with a final notice sent July 27,2010 . A total of 153 organizations completed the survey for a $33 \%$ response rate.

\section{Data Analysis}

Responses from the survey were analyzed using descriptive statistics on all variables. Correlations were performed to determine the relationship between the size of an organization (annual budget and employees) and their adoption of whistleblower protections.

\section{ANALYSIS OF DATA}

\section{Introduction}

The data used in this research study were collected using an electronic survey tool, rmu.vovici.net. The survey was modified by the researcher to determine what impact, if any, the revised IRS Form 990 had on Pennsylvania nonprofit organizations' adaption of Sarbanes-Oxley governance mechanisms into their governance. The survey was adapted from the Iyer \& Watkins [13] study.

On June 28, 2010, The Vovici tool was scheduled to send out 531 electronic surveys. Reminder notices were sent bi-weekly with a final notice sent July 27, 2010. During this time 35 organizations requested removal. These requests fell into the following two categories: 1) the organizations representative felt they did not have time to complete the survey and 2) the organization's representative felt the e-mail soliciting a response for the studies research was spam and subsequently requested removal. An additional 34 organizations representatives requested removal for confidentiality concerns. The actual population for this research study was 462 organizations, making the margin of error for this sample plus or minus $\sqrt{ }(.50(1-.50) / 462) * 1.96=4.56 \%$ A total 153 organizations completed the survey giving the researcher a $33.12 \%$ rate of return.

\section{Survey Results}

After dichotomizing the data in question 3 into organizations with an annual budget less than or equal to $\$ 500,000$ and those with a budget greater than $\$ 500,000$ the researcher found that there were 62 and 91 organizations, respectively. After dichotomizing the data from question 4 into organizations with 100 or fewer employees and those with more than 100 employees, the researcher found that there were 121 and 32 organizations, respectively. When these two new dichotomized variables were cross-classified, all 62 organization with a annual budget of $\$ 500,000$ or less were shown to have 100 or fewer employees (Small / Few), and of those with an annual budget of more than $\$ 500,000,59$ had 100 or fewer employees (Large / Few) and 32 had more than 100 employees (Large / Many). Therefore, there were three types of organizations: 1) those with a small budget and few employees (62);2) those with a large budget and few employees (59); and 3) those with a large budget and many employees (32).

Research question 1 asked Are Pennsylvania nonprofit organizations familiar with the updated whistleblower provisions of the Sarbanes-Oxley Act?

Overall, $76.7 \%$ of the organizations have provisions protecting whistleblowers (Question 16), and $51.7 \%$ indicated that they have made changes to their whistleblower provisions since revisions to the Form 990 or the enactment of Sarbanes-Oxley (Question 18). Again, there was a statistically significant difference by type of organization for both of these aspects. In Small / Few organizations, 50.9\% have provisions protecting whistleblowers, while in Large / Few and Large / Many organizations the proportions were $91.5 \%$ and $96.9 \%$, respectively $X^{2}(2, \mathrm{~N}=150)=$ $36.57, p=<0.0001$. Also, in the Small / Few organizations, 33.3\% have made changes in their whistleblower provisions while in Large / Few and Large / Many the proportions were $65.5 \%$ and $62.5 \%$, respectively $X^{2}(2, \mathrm{~N}=$ $147)=13.77, p=0.001$.

In addition to having provisions to protect whistleblowers, $44.1 \%$ of the organizations indicated that they have a hotline for employees to report unethical activity (Question 17). The proportion with such a mechanism was also 
associated with organizational type. In the Small / Few organizations, $24.6 \%$ have a hotline, while in Large / Few and Large / Many the proportions were $49.2 \%$ and $71.9 \%$, respectively $X^{2}(2, \mathrm{~N}=152)=20.05, p=<0.0001$. The results are summarized below in Table 1 - Whistleblower Protection.

Research question 2 asked Have small Pennsylvania nonprofit organizations that are unfamiliar with the SarbanesOxley Act implemented whistleblower provisions?

Overall, $76.7 \%$ of the organizations responded "yes" to question sixteen indicating that they had whistleblower protections established for their employees, indicating that about three-fourths of the organizations have implemented specific provisions to protect whistleblowers. However, less than one-half (44.1\%) responded "yes" to question seventeen indicating that their organization provides a hotline to report unethical abuses anonymously. Slightly more than half $(51.7 \%)$ of organizations responded "yes" to question eighteen indicating that they have made changes to their whistleblower protection policies since either the revisions to IRS Form 990 or the SarbanesOxley Act. The results are summarized below in Table 2 - Whistleblower protection response among all organizations.

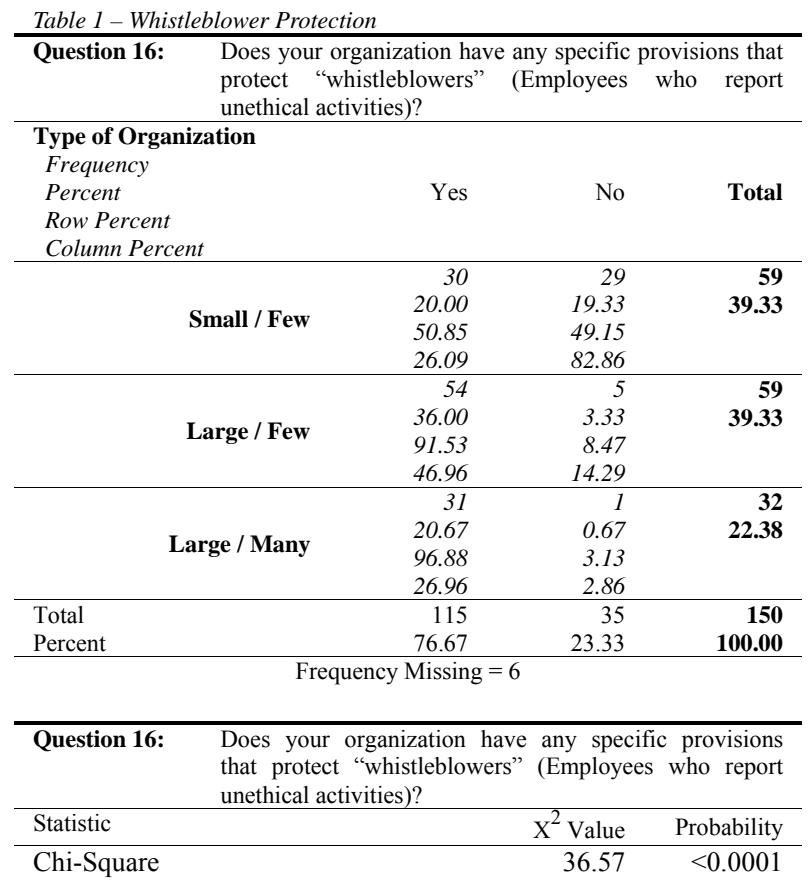

Research question 3 asked Have Pennsylvania nonprofit organizations that are familiar with the whistleblower provisions of the Sarbanes-Oxley Act implemented whistleblower provisions?

When considering only small organizations, those with an annual budget less than $\$ 500,000$, that indicated they were not familiar with the Sarbanes-Oxley Act of 2002 ("not very familiar" or "not at all familiar" as indicated in question 5), only $34.6 \%$ responded "yes" to question 16, indicating that they had implemented specific provisions to protect whistleblowers.

In addition, very few (14.3\%) responded "yes" to question seventeen indicating their organization does not have a hotline to report unethical behavior. Additionally very few (14.8\%) responded "yes" to question eighteen indicating that their organization has made changes to their whistleblower protection policies since either the enactment of Sarbanes-Oxley or the revisions to IRS Form 990. Table 3 - Whistleblower protection response among organizations with budgets less than $\$ 500,000.00$ indicating unfamiliarity with Sarbanes-Oxley. 


\begin{tabular}{|c|c|c|c|c|}
\hline \multirow[t]{2}{*}{ Question 16: } & \multicolumn{4}{|c|}{$\begin{array}{l}\text { Does your organization have any specific provisions that } \\
\text { protect "whistleblowers" (Employees who report } \\
\text { unethical activities)? }\end{array}$} \\
\hline & Frequency & Percent & $\begin{array}{l}\text { Cumulative } \\
\text { Frequency }\end{array}$ & $\begin{array}{c}\text { Cumulative } \\
\text { Percent }\end{array}$ \\
\hline Yes & 115 & 76.67 & 115 & 76.67 \\
\hline No & 35 & 23.33 & 150 & 100.00 \\
\hline \multicolumn{5}{|c|}{ Frequency Missing $=3$} \\
\hline Question 17: & \multicolumn{4}{|c|}{$\begin{array}{l}\text { Does your organization provide a hotline as a means for } \\
\text { employees to report unethical activity anonymously? }\end{array}$} \\
\hline & Frequency & Percent & $\begin{array}{l}\text { Cumulative } \\
\text { Frequency }\end{array}$ & $\begin{array}{c}\text { Cumulative } \\
\text { Percent }\end{array}$ \\
\hline Yes & 67 & 44.08 & 67 & 44.08 \\
\hline \multirow[t]{2}{*}{ No } & 85 & 55.92 & 152 & 100.00 \\
\hline & \multicolumn{3}{|c|}{ Frequency Missing $=1$} & \\
\hline \multirow[t]{2}{*}{ Question 18: } & \multicolumn{4}{|c|}{$\begin{array}{l}\text { Have you made changes to the whistleblower provisions } \\
\text { since either the revision of IRS Form } 990 \text { or the } \\
\text { enactment of Sarbanes-Oxley and the revisions to Form } \\
990 \text { ? }\end{array}$} \\
\hline & Frequency & Percent & $\begin{array}{l}\text { Cumulative } \\
\text { Frequency }\end{array}$ & $\begin{array}{c}\text { Cumulative } \\
\text { Percent }\end{array}$ \\
\hline Yes & 76 & 51.70 & 76 & 51.70 \\
\hline No & 71 & 48.30 & 147 & 100.00 \\
\hline
\end{tabular}

Table 3 - Whistleblower protection response among organizations with budgets less than $\$ 500,000.00$ indicating unfamiliarity with Sarbanes-Oxley.

Question 16: Does your organization have any specific provisions that protect "whistleblowers" (Employees who report unethical activities)?

\begin{tabular}{ccccc}
\hline & Frequency & Percent & $\begin{array}{c}\text { Cumulative } \\
\text { Frequency }\end{array}$ & $\begin{array}{c}\text { Cumulative } \\
\text { Percent }\end{array}$ \\
\hline Yes & 9 & 34.62 & 9 & 34.62 \\
\hline No & 17 & 65.38 & 26 & 100.00 \\
\hline \multicolumn{5}{c}{ Frequency Missing $=3$} \\
\hline
\end{tabular}

\begin{tabular}{ccccc}
\hline Question 17: & \multicolumn{3}{c}{$\begin{array}{l}\text { Does your organization provide a hotline as a means for } \\
\text { employees to report unethical activity anonymously? }\end{array}$} \\
\hline & Frequency & Percent & $\begin{array}{c}\text { Cumulative } \\
\text { Frequency }\end{array}$ & $\begin{array}{c}\text { Cumulative } \\
\text { Percent }\end{array}$ \\
\hline Yes & 4 & 14.29 & 4 & 14.29 \\
\hline No & 24 & 85.71 & 28 & 100.00 \\
\hline \multicolumn{5}{c}{ Frequency Missing $=1$} \\
\end{tabular}

\begin{tabular}{|c|c|c|c|c|}
\hline \multirow[t]{2}{*}{ Question 18: } & \multicolumn{4}{|c|}{$\begin{array}{l}\text { Have you made changes to the whistleblower provisions } \\
\text { since either the revision of IRS Form } 990 \text { or the } \\
\text { enactment of Sarbanes-Oxley and the revisions to Form } \\
990 \text { ? }\end{array}$} \\
\hline & Frequency & Percent & $\begin{array}{l}\text { Cumulative } \\
\text { Frequency }\end{array}$ & $\begin{array}{c}\text { Cumulative } \\
\text { Percent }\end{array}$ \\
\hline Yes & 4 & 14.81 & 4 & 14.81 \\
\hline No & 23 & 85.19 & 27 & 100.00 \\
\hline
\end{tabular}




\section{CONCLUSIONS}

An extensive analysis of the study data resulted in a number of conclusions. These conclusions are based on the highest percentage answer for each survey question.

Research question 1 asked, Are Pennsylvania nonprofit organizations familiar with the updated whistleblower provisions of the Sarbanes-Oxley Act? This research question was answered by the following survey questions: 16) Does your organization have any specific provisions that protect "whistleblowers" (employees who report unethical activities); and 18) Have you made changes to the whistleblower provisions since either the revision of IRS Form 990 or the enactment of Sarbanes-Oxley and the revisions to Form 990?

The majority $(76.7 \%)$ of survey respondents indicated that they had provisions protecting whistleblowers. A little over half $(51.7 \%)$ of surveyed respondents indicated that they had made changes to their whistleblower provisions since either the revisions to IRS Form 990 or the enactment of the Sarbanes-Oxley Act. Among the organizations that indicated they were familiar with these updated provisions to the whistleblower protections, the Small / Few organization types came in last, at $50.9 \%$ for familiarity, while the Large / Few organization type came in at $91.5 \%$, and the Large / Many organization type came in at $96.9 \%$.

Interestingly, slightly less than quarter (23.3\%) of survey respondents had no whistleblower protection plan. This raises some concerns about employee rights at smaller organizations as well as possible liability issues, but should come as no surprise because the whistleblower protection laws were revised when the Sarbanes-Oxley Act was signed into law. The real concern surrounding this finding (because the precentage is so low) was raised earlier in the results of survey question 5, How familiar are you with the Sarbanes-Oxley Act of 2002? Slightly more than quarter $(28.1 \%)$ of all organizations surveyed indicated in their answers to that question that they were very familiar with the Sarbanes-Oxley Act. These percentages appear to be similar and are both reflective of answers received from those at the Small/Few organizations.

Research question(s) 2 and 3 asked, Have small Pennsylvania nonprofit organizations that are unfamiliar with the Sarbanes-Oxley Act implemented whistleblower provisions; and Have Pennsylvania nonprofit organizations that are familiar with the whistleblower provisions of the Sarbanes-Oxley Act implemented whistleblower provisions?

These research questions were answered by the following survey questions: 16) Does your organization have any specific provisions that protect "whistleblowers" (employees who report unethical activities); and 18) Have you made changes to the whistleblower provisions since either the revision of IRS Form 990 or the enactment of Sarbanes-Oxley and the revisions to Form 990?

A large majority (76.7\%) of organizations indicated that they do have specific provisions protecting whistleblowers. Further, more than one-half (51.7\%) have made changes since the revisions to IRS Form 990 or the enactment of the Sarbanes-Oxley Act. However, when looking at only those organizations with budgets less than $\$ 500,000$ that were not familiar with the Sarbanes-Oxley Act, only one-third (34.62\%) indicated they had whistleblower provisions protecting their employees and few (14.81\%) indicated they had made changes since the revisions to IRS Form 990 or the enactment of the Sarbanes-Oxley Act.

For smaller organizations, the costs associated with compliance to these revised regulations has increased their burden and decreased their benefit to the community because of how much of their budgets now must be spent on compliance. The IRS, realizing these burdens, has set reporting requirement thresholds; organizations with gross receipts less than $\$ 25,000$ are required to report annually using Form $990-\mathrm{N}$ e-Postcard designed to ease this reporting burden. Those organizations with gross receipts greater than $\$ 25,000$, however, are required to report annually using Form 990. 


\section{Issues in Information Systems}

Volume XII, No. 1, pp. 44-53, 2011

\section{RECOMMENDATIONS}

The revisions to IRS Form 990 are a step in the right direction for holding organizational leaders accountable for their misconduct. Form 990 mandates changes in nonprofit governance by ensuring that certain financial and regulatory mandates are adhered to. While there is no denying that these types of controls are conducive to good organizational governance, no one has considered how small nonprofit organizations are organized, operate or even consider that there is only one employee, the owner/operator of the organization. Perhaps there is a reason why these numbers are so low and in fact most of these organizations may be one-man shops where the financial impact to implement a policy that only one person must follow is greater that the good as a whole is performing for the community at large.

\section{REFERENCES}

1. Bakale, A. (2009). Revised Form 990: The Evolution of Governance and the Nonprofit World. The Tax Adviser, 40(8), 507-510.

2. Brown, W., \& Nasuti, F. (2005). Sarbanes-Oxley and Enterprise Security: It Governance - What It Takes to Get the Job Done. Information Systems Security, 14(5), 15.

3. Caplan, R. (2009). Irs Releases Redesigned Form 990. The Tax Adviser, 40(4), 254-255.

4. Creswell, J. (2009). Research Design (Third Edition ed.). Los Angeles: Sage.

5. D'Aquila, J. (2004). Tallying the Cost of the Sarbanes-Oxley Act. The CPA Journal, 74(11), 6-9.

6. Fremont-Smith, M. R., \& Kosaras, A. (2003). Wrongdoing by Officers and Directors of Charities: A Survey of Press Reports 1995-2002. SSRN eLibrary, 48. doi: 10.2139/ssrn.451240

7. Gibelman, M., \& Gelman, S. (2000, July 7, 2000). Very Public Scandals: An Analysis of How and Why Nongovernmental Organizations Get in Trouble. Paper presented at the International Society for Third-Sector Research (ISTR), Fourth International Conference, Dublin, Ierland.

8. Gilkeson, N. (2007). For-Profit Scandal in the Nonprofit World: Should States Force Sarbanes-Oxley Provisions onto Nonprofit Corporations? Georgetown Law Journal, 95(3), 831.

9. Grindler, G., \& Jones, J. (2004). Please Step Away from the Shredder and the "Delete" Key: $\S 802$ and 1102 of the Sarbanes-Oxley Act. . The American Criminal Law Review; , 41(1), 67-91.

10. Halloran, P., \& Higgins, G. (2008). The New Form 990. The Bottom Line, 23(7), 22-24.

11. Hempel, J., \& Borrus, A. (2004). Now the Nonprofits Need Cleaning up; Cozy Boardrooms at Colleges and Charities Face Increasing Government Scrutiny. Business Week, June 21, 107.

12. Isaza, J. (2005). Know When to Hold 'Em, When to Destroy 'Em. Information Management Journal, 39(2), 3944.

13. Iyer, V., \& Watkins, A. (2008). Adoption of Sarbanes-Oxley Measures by Nonprofit Organizations: An Empirical Study. Accounting Horizons, 22(3), 255.

14. Mulligan, L. (2007). What's Good for the Goose Is Not Good for the Gander: Sarbanes-Oxley Style Nonprofit Reforms. Michigan Law Review, 105(8), 1981.

15. O'Hare, P. (2002). Sarbanes-Oxley Raises a Red Flag for Not-for-Profits. Healthcare Financial Management, 56(10), 42-44.

16. Orlikoff, J., \& Totten, M. (2004). Applying for-Profit Governance Reforms. Healthcare Executive, 19(3), 52, 54.

17. Pomeroy, A. (2006). Sarbanes-Oxley Costs Affect Smaller Companies the Most. HRMagazine, 51(8), 14-16.

18. Public Company Accounting Reform and Investor Protection Act, 116, Pub. L. No. 107-204, 745 Stat. 66 (2002 July 30, 2002).

19. Schneider, G., \& Bruton, C. (2007). Sarbanes-Oxley Compliance: New Oppertunties for Information Technology Professionals. Academy of Information and Management Sciences Journal, 10(2), 79-89.

20. Sector, i. (2009). Accountability. Retrieved November 13, 2009, from http://www.independentsector.org/accountability old?s=accountability

21. Sector, I. (2010). Irs Form 990. Retrieved November 9, 2010, from http://www.independentsector.org/form 990

22. Silk, T., \& Fei, R. (2005). California's Nonprofit Integrity Act of 2004 (Sb 1262). The International Journal for 


\section{Issues in Information Systems}

Volume XII, No. 1, pp. 44-53, 2011

Not-for-Profit Law, 7(2).

23. Smoker, K., \& Mammano, K. (2009). The Revision of Federal Form 990: A Move toward Sox-Like Reform in the Nonprofit Sector. The CPA Journal, 79(7), 52-55.

24. Steuer, J. (2007). Surprise! Sarbanes-Oxley (at Least Some of It) Is Law for Nonprofits. Pennsylvania CPA Journal, 78(1), 22-23.

25. Wyllie, B. (2009). The Redesigned Form 990. Journal of Accountancy, 207(3), 72-78. 